\title{
The use of a DNA stabilizer in human dental tissues stored under different temperature conditions and time intervals
}

\author{
Andrea Sayuri Silveira Dias TERADA ${ }^{1}$, Luiz Antonio Ferreira da SILVA ${ }^{2}$, Rodrigo GALO ${ }^{3}$, Aline de AZEVEDO ${ }^{3}$, Raquel \\ Fernanda GERLACH ${ }^{3}$, Ricardo Henrique Alves da SILVA ${ }^{3}$
}

1- Ribeirão Preto School of Medicine, University of São Paulo, Ribeirão Preto, SP, Brazil.
2- Forensic DNA Laboratory, Federal University of Alagoas, Maceió, AL, Brazil.
3- Ribeirão Preto School of Dentistry, University of São Paulo, Ribeirão Preto, SP, Brazil.

Corresponding address: Andrea Sayuri Silveira Dias Terada - Faculdade de Medicina de Ribeirão Preto - USP - Departamento de Patologia e Medicina Legal - CEMEL - Rua: Tenente Catão Roxo, s/nº - Monte Alegre - Ribeirão Preto - SP - Brazil - 14051-140 - Phone: (+55) 16 98194-6537 - e-mail: andrea. terada@usp.br

Submitted: December 10, 2013 - Modification: May 20, 2014 - Accepted: May 20, 2014

\section{ABSTRACT}

\begin{abstract}
$\mathrm{O}$ bjective: The present study evaluated the use of a reagent to stabilize the DNA extracted from human dental tissues stored under different temperature conditions and time intervals. Material and Methods: A total of 161 teeth were divided into two distinct groups: intact teeth and isolated dental pulp tissue. The samples were stored with or without the product at different time intervals and temperature. After storage, DNA extraction and genomic DNA quantification were performed using real-time PCR; the fragments of the 32 samples that represented each possible condition were analyzed to find the four preselected markers in STR analysis. Results: The results of the quantification showed values ranging from 0.01 to $10,246.88 \mathrm{ng} / \mu \mathrm{L}$ of DNA. The statistical difference in the quantity of DNA was observed when the factors related to the time and temperature of storage were analyzed. In relation to the use of the specific reagent, its use was relevant in the group of intact teeth when they were at room temperature for 30 and 180 days. The analysis of the fragments in the 32 selected samples was possible irrespective of the amount of DNA, confirming that the STR analysis using an automated method yields good results. Conclusions: The use of a specific reagent showed a significant difference in stabilizing DNA in samples of intact human teeth stored at room temperature for 30 and 180 days, while the results showed no justification for using the product under the other conditions tested.
\end{abstract}

Keywords: Forensic dentistry. Molecular biology. DNA. Teeth. Stabilization

\section{INTRODUCTION}

The application of techniques involving molecular biology in forensic dentistry represents a scientific achievement ${ }^{1,2,3}$. The DNA can be extracted from different regions of the tooth ${ }^{4}$ and this source of biological material is indicated in cases of carbonization, since the resistance and durability, associated with dental positioning, offer protection to various exogenous factors ${ }^{5,9}$.

When considering forensic samples, which generally have small DNA fragments, care must be taken in the maintenance of the material, since any loss can impair the analysis of these samples ${ }^{15,16,18}$.
One of the major difficulties encountered by experts is the storage of these samples ${ }^{8}$ because the adverse conditions found at the crime scenes may affect the stability of the material. DNA degradation is a complex phenomenon that begins with autolysis, followed by aerobic and bacterial destruction of the cell, which depends on the level of water, oxygen, and most importantly, the temperature of the local environment ${ }^{1,2}$.

The most common technique used for preserving the integrity of the samples has been freezing?. However, other methods for stabilizing the samples have been used ${ }^{14}$, and at present there are products on the market that promise to stabilize 
the DNA immediately after the immersion of the biological sample into the product $6,10,11,13$.

The aim of this study was to assess the use of Allprotect ${ }^{\mathrm{TM}}$ Tissue Reagent (Qiagen, Hilden, North Rhine-Westphalia, Germany) to stabilize the DNA from human dental tissues stored under different temperature (room temperature and under refrigeration) conditions and time intervals $(1,7,30$ and 180 days).

\section{MATERIAL AND METHODS}

161 teeth from dental extractions of healthy maxillary and mandibular third molars obtained in graduate and/or post-graduate clinics of the Ribeirão Preto School of Dentistry, University of São Paulo (FORP-USP), SP, Brazil were used. After the surgical procedure, the dental elements were cleaned with sterile gauze and saline, to later be divided into two distinct groups of study: intact teeth and pulp tissue. Prior to the division of the groups, the teeth were kept in a refrigerator $\left(-20^{\circ} \mathrm{C}\right)$.

\section{Sample group - intact teeth}

Each intact tooth was numbered and stored under different conditions, as shown in Figure 1 $(n=5)$. In the samples in which Allprotect ${ }^{\mathrm{TM}}$ Tissue Reagent was used, the product was poured into a sterile centrifuge plastic bottle - Falcon type (Axygen, Inc; Tewksbury, MA, USA) using the dispensing valve present in the bottle.

\section{Sample group - dental pulp}

The extraction of the dental pulp was performed by cutting the teeth slowly in a horizontal direction in the region of the cementoenamel junction using a low speed motor with the aid of a sterile carborundum disk that was replaced after every tooth. After the tooth was sectioned, the pulp tissue was removed using sterile and individual endodontic instruments and the samples were stored in $0.5 \mathrm{ml}$ microcentrifuge tubes (Axygen, Inc; Tewksbury, MA, USA). Each dental pulp was numbered and kept under different conditions, as shown in Figure $1(n=5)$.

\section{Positive control}

One tooth was stored at $-20^{\circ} \mathrm{C}$ for 180 days. This positive control was determined to ensure the viability of the extraction from the dental pulp using a commercial kit and following the standard protocol for storage $\left(-20^{\circ} \mathrm{C}\right)$. This sample was not used to compare the effects of the product, and therefore the results of the quantification of the DNA extracted from this group were not used in the statistical analysis.

\section{Extraction of DNA}

The genomic DNA was extracted using the Qiaamp $^{\text {TM }}$ DNA Micro kit (Qiagen, Hilden, North Rhine-Westphalia, Germany) using the protocol for genomic DNA extraction from tissues.

\section{Quantification of DNA by real-time PCR}

Quantification by real-time PCR was performed using the 7500 Real-Time PCR System with the SDS software and the samples of the intact teeth and dental pulp were quantified at different times. To quantify the total genomic DNA present in the sample, the Quantifiler ${ }^{\mathrm{TM}}$ Human DNA Quantification kit (Applied Biosystems, Foster City, California, USA) was used in accordance with the manufacturer's protocol.

Analysis of DNA fragments - STR analysis

At the end, 32 samples were randomly selected, representing every possible condition. It was examined if amplification occurred from the use of the following four pre-selected markers with significant polymorphism: FGA (VIC - GGCTGCAGGGCATAACATTA and ATTCTATGACTITGCGCTTCAGGA) for the 308-464 bp products; D3S1358 (ACTGCAGTCCAATCTGGGT and VIC - ATGAAATCAACAGAGGCTTGC) for the 99-147 bp products; D7S820 (VIC - ATGTTGGTCAgGTGACTATG and GATTCCACATTTATCCTCATTGAC) for the 211-251 bp products and D16S539 (GGGGGTCTAAGAGCTTGTAAAAAG and VIC TTTGTGTGTGCATCTGTAAGCATGTATC) for the 260-304 bp products.

These samples were standardized and diluted in TE buffer and an amplification reaction was performed so that they would contain a maximum

\begin{tabular}{|c|c|c|c|c|c|c|c|}
\hline \multicolumn{8}{|c|}{ Room temperature $\left(24\right.$ to $37^{\circ} \mathrm{C}$ ) } \\
\hline \multicolumn{2}{|c|}{180 days } & \multicolumn{2}{|c|}{30 days } & \multicolumn{2}{|c|}{7 days } & \multicolumn{2}{|c|}{1 day } \\
\hline Allprotect ${ }^{\mathrm{TM}}$ & No product & Allprotect ${ }^{\mathrm{TM}}$ & No product & Allprotect ${ }^{\mathrm{TM}}$ & No product & Allprotect ${ }^{\mathrm{TM}}$ & No product \\
\hline \multicolumn{8}{|c|}{ Temperature $\left(4\right.$ to $\left.8^{\circ} \mathrm{C}\right)$} \\
\hline \multicolumn{2}{|c|}{180 days } & \multicolumn{2}{|c|}{30 days } & \multicolumn{2}{|c|}{7 days } & \multicolumn{2}{|c|}{1 day } \\
\hline Allprotect ${ }^{\mathrm{TM}}$ & No product & Allprotect ${ }^{\mathrm{TM}}$ & No product & Allprotect ${ }^{\mathrm{TM}}$ & No product & Allprotect ${ }^{\mathrm{TM}}$ & No product \\
\hline
\end{tabular}

Figure 1- Description of experimental groups $(n=5)$ 
concentration of $20 \mathrm{ng} / \mu \mathrm{L}$ of DNA.

The amplification of the samples was performed in a TC-412 Thermal Cycler (Techne, Stafford, Staffordshire, UK) and after an initial denaturation step at $95^{\circ} \mathrm{C}$ for 2 minutes the PCR was carried out for 28 cycles using the following conditions: denaturation at $94^{\circ} \mathrm{C}$ for 1 minute, annealing at $59^{\circ} \mathrm{C}$ for 1 minute, extension at $72^{\circ} \mathrm{C}$ for 1 minute, followed by a final extension step at $60^{\circ} \mathrm{C}$ for 1 hour.

One $\mu \mathrm{L}$ of the "Amplicon" was then added to $10 \mu \mathrm{L}$ formamide and taken to the ABI Prism 310 Genetic Analyzer (Applied Biosystems, Foster City, California, USA) using the Gene Mapper ${ }^{\text {TM }}$ ID software (Applied Biosystems, Foster City, California, USA).

\section{Statistical analysis}

The experimental data were statistically analyzed by Kruskal-Wallis test (non-parametric test) to determine the influence of using Allprotect ${ }^{\mathrm{TM}}$ Tissue Reagent or not to stabilize DNA from human dental tissues under different temperature conditions and time periods. The Mann-Whitney test was used for multiple comparisons ( $p \leq .05)$.

\section{RESULTS}

The presence of genomic DNA was observed in all samples. The values of the quantification by real-time PCR were expressed in $\mathrm{ng} / \mu \mathrm{L}$ and the amount of DNA was highly variable among the samples ( 0.01 to $10,246.88 \mathrm{ng} / \mu \mathrm{L})$. The statistical analysis was performed from the values found in each group, and the values obtained are shown in Table 1 (intact teeth) and Table 2 (pulp tissue).

In this study it was observed that there was statistical difference in the amount of DNA obtained when analyzing the factors related to the time and temperature of storage. In relation to the use of the specific product Allprotect ${ }^{\mathrm{TM}}$ Tissue Reagent, it was relevant in the group of intact teeth when they were at room temperature for 30 and 180 days.

In the second laboratory stage, in which the fragments of 32 samples were analyzed, it was found that, despite the variation in the amount of DNA, the analysis of alleles of the four selected regions was possible in all samples selected. Figure 2 shows an example of how the genetic analyzer provides the results.

Table 1- Mean and standard deviation of the quantification of genomic DNA by real-time PCR in the group of intact teeth, samples 1-80 (ng/ $\mathrm{LL})$

\begin{tabular}{|c|c|c|c|c|}
\hline \multirow[t]{3}{*}{ Days } & \multicolumn{4}{|c|}{ Intact tooth } \\
\hline & \multicolumn{2}{|c|}{ Allprotect } & \multicolumn{2}{|c|}{ No product } \\
\hline & $4-8^{\circ} \mathrm{C}$ & $23-34^{\circ} \mathrm{C}$ & $4-8^{\circ} \mathrm{C}$ & $23-34^{\circ} \mathrm{C}$ \\
\hline 1 & $1,064.62 \pm 461.64^{\mathrm{aA}}$ & $481.62 \pm 52.87^{\mathrm{aA}}$ & $921.12 \pm 204.95^{\mathrm{aA}}$ & $577.06 \pm 279.95^{\mathrm{aA}}$ \\
\hline 7 & $1,067.90 \pm 290.18^{\mathrm{aA}}$ & $598.59 \pm 372.29^{\mathrm{aA}}$ & $418.08 \pm 161.08^{\mathrm{aA}}$ & $756.42 \pm 343.70^{\mathrm{aA}}$ \\
\hline 30 & $297.49 \pm 98.57^{\mathrm{aA}}$ & $1,592.52 \pm 616.95^{\mathrm{aA}}$ & $886.14 \pm 473.76^{\mathrm{aA}}$ & $7.26 \pm 3.23^{\mathrm{bB}}$ \\
\hline 180 & $1,003.77 \pm 428.06^{\mathrm{abA}}$ & $2,524.82 \pm 854.32^{\mathrm{aA}}$ & $504.63 \pm 274.24^{\mathrm{bcA}}$ & $20.57 \pm 10.48^{\mathrm{cB}}$ \\
\hline
\end{tabular}

(Different lowercase letters indicate statistically significant differences between columns; different uppercase letters indicate statistically significant differences between lines)

Table 2- Mean and standard deviation of the quantification of genomic DNA by real-time PCR in the group of dental pulp, samples 81-160 (ng/ $\mu \mathrm{L})$

\begin{tabular}{|c|c|c|c|c|}
\hline \multirow[t]{3}{*}{ Days } & \multicolumn{4}{|c|}{ Dental pulp } \\
\hline & \multicolumn{2}{|c|}{ Allprotect } & \multicolumn{2}{|c|}{ No product } \\
\hline & $4-8^{\circ} \mathrm{C}$ & $23-34^{\circ} \mathrm{C}$ & $4-8^{\circ} \mathrm{C}$ & $23-34^{\circ} \mathrm{C}$ \\
\hline 1 & $394.77 \pm 116.57^{\mathrm{aA}}$ & $1,110.83 \pm 467.40^{\mathrm{aA}}$ & $604.28 \pm 231.91^{\mathrm{aA}}$ & $1,130.88 \pm 189.15^{\mathrm{aA}}$ \\
\hline 7 & $1,417.17 \pm 356.73^{\mathrm{aA}}$ & $1,345.13 \pm 516.23^{\mathrm{aA}}$ & $844.94 \pm 341.35^{\mathrm{aA}}$ & $379.41 \pm 190.53^{\mathrm{aA}}$ \\
\hline 30 & $787.97 \pm 325.76^{\mathrm{aA}}$ & $1,279.79 \pm 686.13^{\mathrm{aA}}$ & $1,457.28 \pm 738.56^{\mathrm{aA}}$ & $1,025.09 \pm 685.44^{\mathrm{aA}}$ \\
\hline 180 & $3,416.48 \pm 1826.41^{\mathrm{aA}}$ & $1,533.69 \pm 519.53^{\mathrm{abA}}$ & $2,260.70 \pm 454.02^{\mathrm{aA}}$ & $82.33 \pm 66.08^{\mathrm{bA}}$ \\
\hline
\end{tabular}

(Different lowercase letters indicate statistically significant differences between columns; different uppercase letters indicate statistically significant differences between lines) 


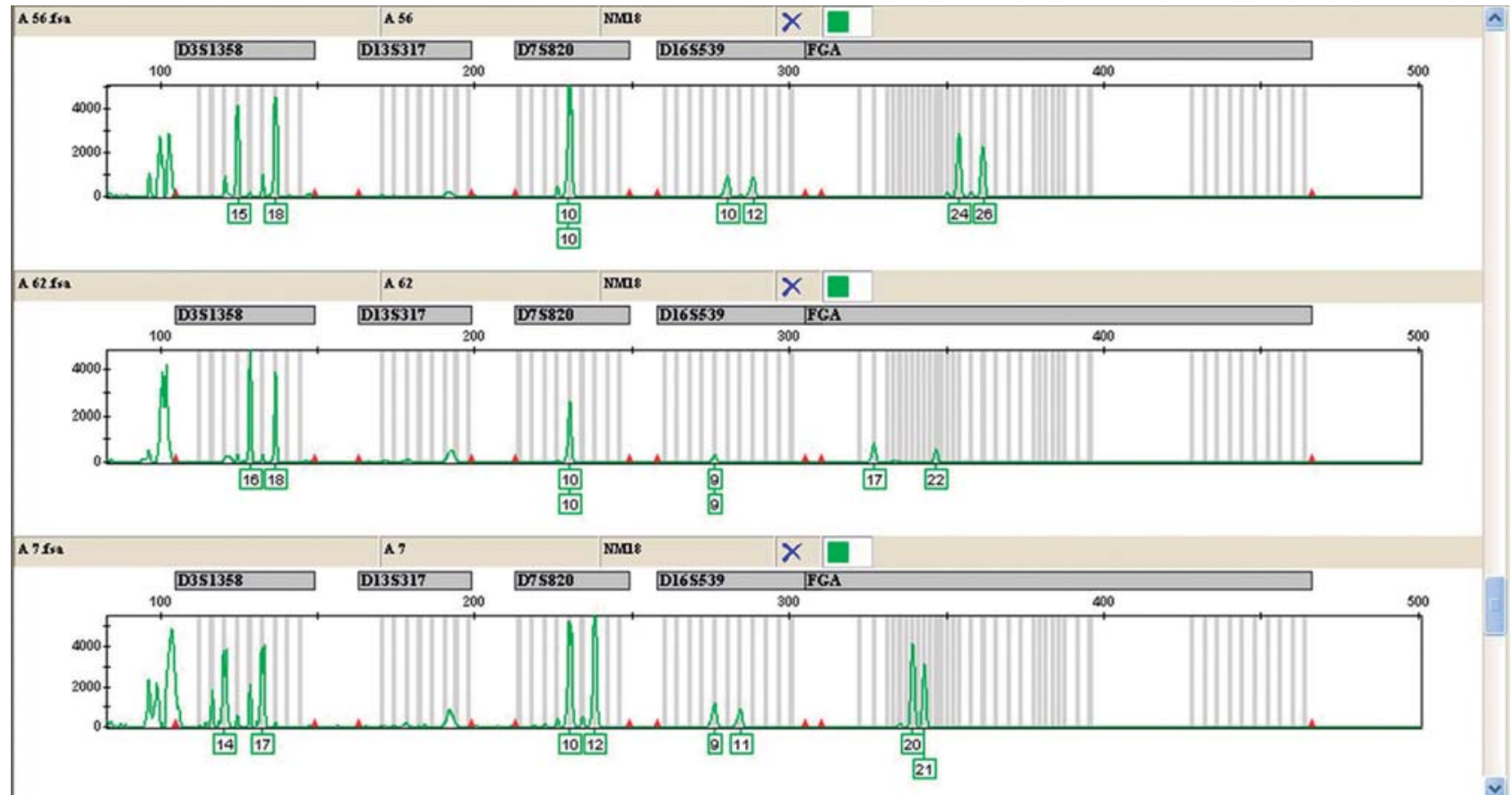

Figure 2- Image of the Gene Mapper ${ }^{\mathrm{TM}}$ ID software (Applied Biosystems, USA) for the STR analysis in three differents samples

\section{DISCUSSION}

Some studies have shown how environmental factors related to time, temperature, and humidity can influence the quality and quantity of $\mathrm{DNA}^{1,2,12,15,16,17}$. Knowing this is important to define the storage protocols in order to maintain the quality and stability of the genetic material of forensic samples.

With regard to the time factor, Pfeiffer, et al. ${ }^{15}$ (1999) found that the concentration of DNA was reduced by $90 \%$ after storing teeth in the soil for a six-week time period. The results of the present study also showed that degradation is associated with the time factor when the intact teeth are stored at room temperature.

As for the variation in temperature, Schwartz, et al. ${ }^{16}$ (1991) observed that the variation of $4^{\circ} \mathrm{C}$, $25^{\circ} \mathrm{C}$ and $37^{\circ} \mathrm{C}$ was not decisive for obtaining DNA with high molecular weight from dental pulps despite $\mathrm{pH}$, moisture, soil conditions and time of burial. In the present study, although it was possible to obtain DNA, a difference was found between the samples stored at room temperature and those refrigerated.

Because the temperature influences the amount of DNA, dry storage at low temperatures is indicated to preserve the biological material7,14. However, it is known that, in some situations the maintenance of the samples under appropriate conditions and at low temperatures may be difficult if, for example, access to the location of the crime with the necessary materials is not possible ${ }^{6}$.

Within this forensic context, using products that stabilize DNA molecules is an alternative to maintain the quality of the sample until it can be taken to the appropriate laboratories ${ }^{14}$. Accordingly, tests involving the efficiency of these products should be conducted to justify their use.

In this study the intact teeth kept under refrigeration showed no significant improvement in the amount of DNA when the product was used, as well as the storage of dental pulp, in which using the product or not showed no significant differences under the two temperature conditions. These results are similar to those found in the study of Mee, et al.11 (2011), who observed no differences in the quality of the DNA extracted from samples of breast tissues when using the product or not was compared before freezing.

In this study, it was not considered the use of the product in frozen samples since, in the forensic context, storage of the tissue in preservatives would be interesting only until the sample could be frozen and transported to the laboratory. When frozen or under refrigeration ( 4 to $8^{\circ} \mathrm{C}$ ), the results showed that the use of the product was not relevant, which does not justify the extra cost.

Furthermore, it were analyzed longer time intervals as, according to Nagy ${ }^{14}$ (2010), the tests performed so far with these stabilizers did not include this variable. It was observed that the use of Allprotect ${ }^{\mathrm{TM}}$ Tissue Reagent in intact teeth kept at room temperature for 30 and 180 days showed a significant difference in the amount of DNA $(p=0.008)$, which indicates its use when samples need to be kept under this condition for extended periods of time. 
However, despite this difference found in storage for 30 and 180 days at room temperature, the product is still considered expensive in comparison with other preservation methods, which would not justify its use in forensic context because within this time interval the samples could be sent to appropriate locations and stored following the standard freezing protocols.

In forensic investigation involving biological samples for the application of genetic testing, maintenance is important for the quality of the material. By opting for the extraction of DNA from dental tissues it is understood that other common sources, e.g., extraction of DNA from blood, are not possible and hence the material might be exposed to degradation factors.

For this reason, attention regarding the preservation of samples must be taken in order not to harm future laboratory procedures ${ }^{8,18}$. Therefore, further studies related to preservation methods should be conducted to ensure a reliable method for the preservation of the samples, particularly in relation to stabilizing agents. The results have shown that the effectiveness is limited and further investigations are required.

\section{CONCLUSION}

It may be concluded that the use of Allprotect ${ }^{\mathrm{TM}}$ Tissue Reagent showed a significant difference in stabilizing DNA in samples of intact human teeth stored at room temperature for 30 and 180 days, while the results showed no justification for using the product under the other conditions tested.

\section{ACKNOWLEDGMENT}

Financial subsidy - São Paulo Research Foundation (FAPESP): 2011/08124-5.

\section{CONFLICT OF INTEREST}

The results of this study were presented in scientific congress IOFOS - Italy 2013. The summary published in the annals of the event is available at: J Forensic Odontostomatol. 2013 Oct 1;31 Suppl 1:134-5.

\section{REFERENCES}

1- Alaeddini R, Walsh SJ, Abbas A. Forensic implications of genetic analyses from degraded DNA - a review. Forensic Sci Int Genet. 2010;4(3):148-57.

2- Bender K, Farfán MJ, Schneider PM. Preparation of degraded human DNA under controlled conditions. Forensic Sci Int. 2004;139:135-40.

3- Datta P, Datta SS. Role of deoxyribonucleic acid technology in forensic dentistry. J Forensic Dent Sci. 2012;4(1):42-6.
4- Gaytmenn R, Sweet D. Quantification of forensic DNA from various regions of human teeth. J Forensic Sci. 2003;48(3):622-5. 5- Girish K, Rahman FS, Tippu SR. Dental DNA fingerprinting in identification of human remains. J Forensic Dent Sci. 2010;2(2):63-8.

6- Grotzer MA, Patti R, Geoerger B, Eggert A, Chou TT, Phillips PC. Biological stability of RNA isolated from RNAlater-treated brain tumor and neuroblastoma xenografts. Med Pediatr Oncol. $2000 ; 34(6): 438-42$

7- Höss M, Jaruga P, Zastawny TH, Dizdaroglu M, Pääbo S. DNA damage and DNA sequence retrieval from ancient tissues. Nucleic Acids Res. 1996;24(7):1304-7.

8- Lee HC, Ladd C. Preservation and collection of biological evidence. Croat Med J. 2001;42(3):225-8.

9- Manjunath BC, Chandrashekar BR, Mahesh M, Vatchala Rani RM. DNA profiling and forensic dentistry - a review of the recent concepts and trends. J Forensic Leg Med. 2011;18(5):191-7. 10- Medeiros M, Sharma VK, Ding R, Yamaji K, Li B, Muthukumar T, et al. Optimization of RNA yield, purity and mRNA copy number by treatment of urine cell pellets with RNAlater. J Immunol Methods. 2003;279(1-2):135-42.

11- Mee BC, Carroll P, Donatello S, Connolly E, Griffin M, Dunne $B$. Maintaining breast cancer specimen integrity and individual or simultaneous extraction of quality DNA, RNA, and proteins from Allprotect-stabilized and nonstabilized tissue samples. Biopreserv Biobank. 2011;9(4):389-98.

12- Muruganandhan J, Sivakumar G. Practical aspects of DNA-based forensic studies in dentistry. J Forensic Dent Sci. $2011 ; 3(1): 38-45$.

13- Mutter GL, Zahrieh D, Liu C, Neuberg D, Finkelstein D, Baker $\mathrm{HE}$, et al. Comparison of frozen and RNALater solid tissue storage methods for use in RNA expression microarrays. BMC Genomics. $2004 ; 5: 88$.

14- Nagy ZT. A hands-on overview of tissue preservation methods for molecular genetic analyses. Org Divers Evol. 2010;10(1):91105.

15- Pfeiffer H, Hühne J, Seitz B, Brinkmann B. Influence of soil storage and exposure period on DNA recovery from teeth. Int J legal Med. 1999;112(2):142-4.

16- Schwartz TR, Schwartz EA, Mieszerski L, Mcnally L, Kobilinsky L. Characterization of deoxyribonucleic acid (DNA) obtained from teeth subjected to various environmental conditions. J Forensic Sci. 1991;36(4):979-90.

17- Silva RH, Quiezi R, Bertolacini CD, Carvalho SP, Gasque KC, Almeida-e-Silva CT, et al. Human identification analysis using PCR from the root portion of dental elements under different conditions of temperature and exposure time. RSBO. 2012;9(1):67-73.

18- Silva RH, Sales-Peres A, Oliveira RN, Oliveira FT, Sales-Peres $\mathrm{SH}$. Use of DNA technology in forensic dentistry. J Appl Oral Sci. 2007;15(3):156-61. 